\title{
New Isocoumarin Derivatives and Meroterpenoids from the Marine Sponge-Associated Fungus Aspergillus similanensis sp. nov. KUFA 0013
}

\section{Chadaporn Prompanya ${ }^{1,2}$, Tida Dethoup ${ }^{3}$, Lucinda J. Bessa ${ }^{1,2}$, Madalena M. M. Pinto ${ }^{2,4}$, Luís Gales ${ }^{1,5}$, Paulo M. Costa ${ }^{1,2}$, Artur M. S. Silva ${ }^{6}$ and Anake Kijjoa ${ }^{1,2, *}$}

1 ICBAS - Instituto de Ciências Biomédicas de Abel Salazar, Universidade do Porto, Rua de Jorge Viterbo Ferreira 228, 4050-313 Porto, Portugal; E-Mails: chadaporn@buu.ac.th (C.P.); lbessa@ciimar.up.pt (L.J.B.); lgales@ibmc.up.pt (L.G.); pmcosta@icbas.up.pt (P.M.C.)

2 Interdisciplinary Centre of Marine and Environmental Research (CIIMAR), Rua dos Bragas 289, 4050-123 Porto, Portugal

3 Department of Plant Pathology, Faculty of Agriculture, Kasetsart University, Bangkok 10240, Thailand; E-Mail: agrtdd@ku.ac.th

4 Centro de Química Medicinal da Universidade do Porto (CEQUIMED-UP) and Laboratório de Química Orgânica e Farmacêutica, Departamento de Ciências Químicas, Faculdade de Farmácia, Universidade do Porto, Rua de Jorge Viterbo 228, 4050-313 Porto, Portugal;

E-Mail:madalena@ff.up.pt

5 Instituto de Biologia Celular e Molecular (IBMC), Universidade do Porto, 4099-003 Porto, Portugal

6 Departamento de Química \& QOPNA, Universidade de Aveiro, 4810-193 Aveiro, Portugal;

E-Mail: artur.silva@ua.pt

* Author to whom correspondence should be addressed; E-Mail: ankijjoa@icbas.up.pt;

Tel.: +351-2-2042-8331; Fax: +351-2-2042-8090.

External Editor: Orazio Taglialatela-Scafati

Received: 28 July 2014; in revised form: 24 September 2014 / Accepted: 25 September 2014 / Published: 14 October 2014

\footnotetext{
Abstract: Two new isocoumarin derivatives, including a new 5-hydroxy-8-methyl-2H, 6H-pyrano[3,4-g]chromen-2,6-dione (1) and 6,8-dihydroxy-3,7-dimethylisocoumarin (2b), a new chevalone derivative, named chevalone $\mathrm{E}(\mathbf{3})$, and a new natural product pyripyropene $\mathrm{S}$ (6) were isolated together with 6, 8-dihydroxy-3-methylisocoumarin (2a), reticulol (2c), p-hydroxybenzaldehyde, chevalone B, chevalone C, S14-95 (4), and pyripyropene E (5) from the ethyl acetate extract of the undescribed marine sponge-associated fungus
} 
Aspergillus similanensis KUFA 0013. The structures of the new compounds were established based on 1D and 2D NMR spectral analysis, and in the case of compound 3, $\mathrm{X}$-ray analysis was used to confirm its structure and the absolute configuration of its stereogenic carbons. Compounds 1, 2a-c and 3-6 were evaluated for their antimicrobial activity against Gram-positive and Gram-negative bacteria, Candida albicans ATCC 10231, and multidrug-resistant isolates from the environment. Chevalone E (3) was found to show synergism with the antibiotic oxacillin against methicillin-resistant Staphylococcus aureus (MRSA).

Keywords: Aspergillus similanensis; similanpyrones; isocoumarins; meroditerpenes; pyripyropenes; chevalones

\section{Introduction}

Neosartorya is a teleomorphic (sexual) state of Aspergillus section Fumigati. Although Neosartorya species (Trichocomaceae) have not been as extensively investigated for their secondary metabolites as Aspergillus, they have recently been shown to be an interesting source of many bioactive compounds [1-9]. In our ongoing search for new natural products with antibacterial activity produced by the marine-derived fungi of the genus Neosartorya, we have investigated the secondary metabolites of a Thai collection of a new species of Neosartorya, isolated from the marine sponge Rhabdermia sp., collected from the Similan Islands, Phang Nga Province, Southern Thailand. However, in order to comply with the recent "International Code of Nomenclature for algae, fungi and plants (The Melbourne Code)", the strain was renamed Aspergillus similanensis (KUFA0013). The ethyl acetate extract of its culture furnished, besides chevalones B and C [9,10], p-hydroxybenzaldehyde, reticulol (2c) [11], 6,8-dihydroxy-3methylisocoumarin (2a) [12], a meroterpenoid S14-95 (4) [13], pyripyropene E (5) [14], two new isocoumarins which we have named similanpyrones A (1) and B (2b), a new chevalone analog (3), and a new natural product which we have named pyripyropene S (6) [15] (Figure 1). Compounds 1, 2a-c, 3-6 were evaluated for their antimicrobial activity against Gram positive (Staphylococcus aureus ATCC 25923 and Bacillus subtilis ATCC 6633) and Gram negative (Escherichia coli ATCC 25922 and Pseudomonas aeruginosa ATCC 27853) bacteria, Candida albicans ATCC 10231, as well as multidrug-resistant isolates from the environment. 
Figure 1. Secondary metabolites from Aspergillus similanensis KUFA0013.
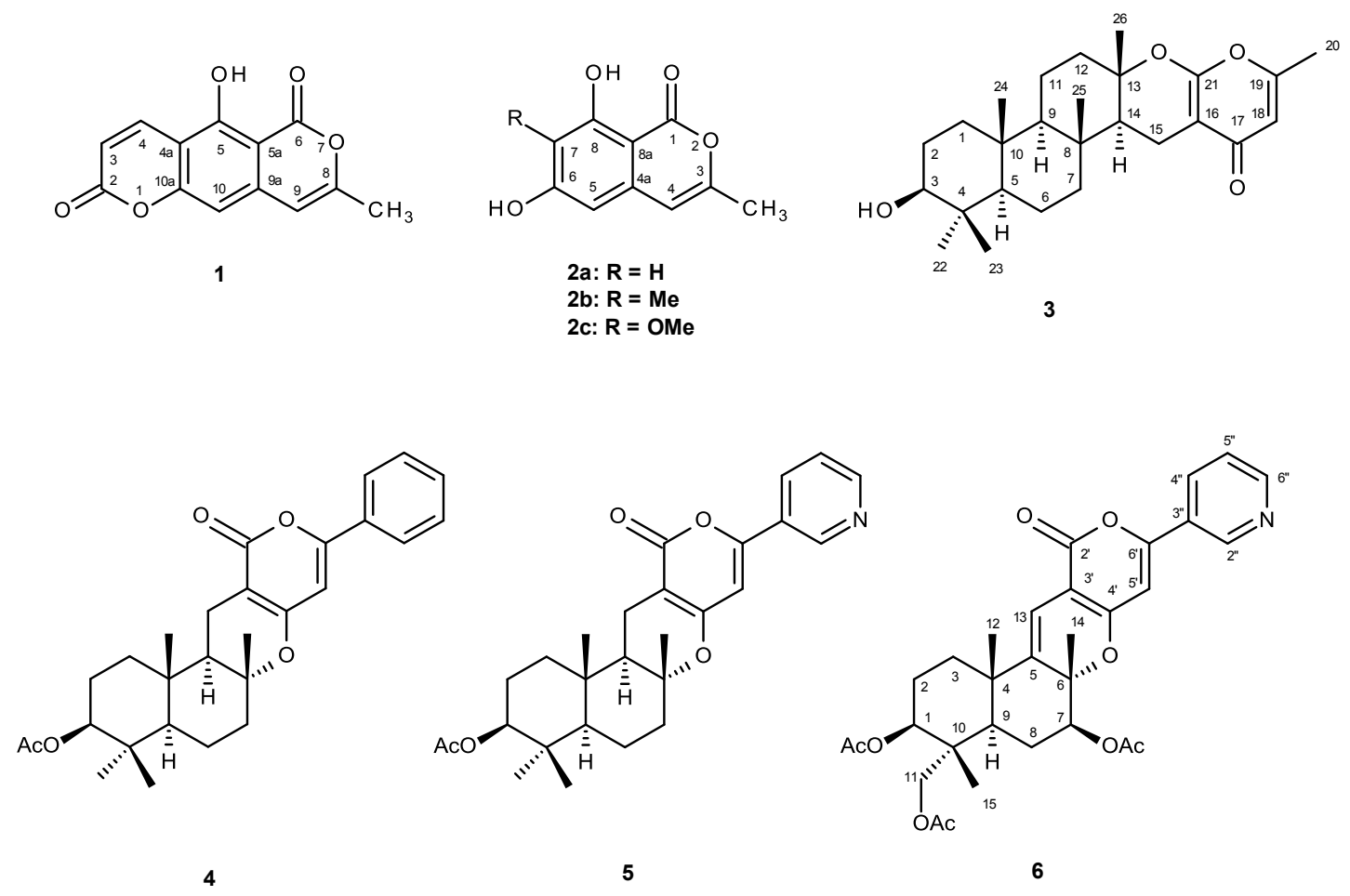

\section{Results and Discussion}

Compound 1 was isolated as white solid (mp, 322-323 $\left.{ }^{\circ} \mathrm{C}\right)$, and its molecular formula $\mathrm{C}_{13} \mathrm{H}_{8} \mathrm{O}_{5}$ was established on the basis of the (+)-HRESIMS $m / z 245.0450[\mathrm{M}+\mathrm{H}]^{+}$, indicating ten degrees of unsaturation. The IR spectrum showed absorption bands for hydroxyl $\left(3446 \mathrm{~cm}^{-1}\right)$, conjugated lactone carbonyl $\left(1748,1698 \mathrm{~cm}^{-1}\right)$, aromatic $\left(1658 \mathrm{~cm}^{-1}\right)$ and olefin $\left(1634,1464 \mathrm{~cm}^{-1}\right)$ groups. The ${ }^{13} \mathrm{C} \mathrm{NMR}$ (Supplementary Information, Figure S2), DEPTs and HSQC spectra (Table 1, Supplementary Information, Figure S4) revealed the presence of two conjugated ester carbonyls ( $\delta_{\mathrm{C}} 166.3$ and 159.7), six quaternary $\mathrm{sp}^{2}\left(\delta_{\mathrm{c}} 101.3,107.3,130.0,140.1,156.2\right.$ and 160.3$)$, four methine $\mathrm{sp}^{2}\left(\delta_{\mathrm{c}} 102.7,104.6\right.$, 114.1, and 137.8) and one methyl $\left(\delta_{\mathrm{C}} 19.6\right)$ carbons. The ${ }^{1} \mathrm{H}$ NMR spectrum (Supplementary Information, Figure S1) revealed, besides a singlet of the hydrogen bonded hydroxyl proton at $\delta \mathrm{H} 11.90$, two doublets of the cis-olefinic protons at $\delta \mathrm{H} 8.13(\mathrm{~J}=9.8 \mathrm{~Hz})$ and $6.36(\mathrm{~J}=9.8 \mathrm{~Hz})$, two singlets at $\delta_{\mathrm{H}}$ 6.33 and 6.70, and one methyl singlet at $\delta_{\mathrm{H}}$ 2.33. The COSY spectrum (Table 1; Supplementary Information, Figure S3) exhibited cross peak between the singlet at $\delta \mathrm{H} 6.33$ (H-9) and the methyl singlet at $\delta_{\mathrm{H}} 2.33$ (Me-8), suggesting that they were allylically coupled. On the other hand, the HMBC spectrum (Table 1; Supplementary Information, Figure S5) showed cross peaks of H-9 to C-8 ( $\left.\delta_{\mathrm{C}} 156.2\right)$, C-9a ( $\delta \mathrm{c} 130.3), \mathrm{C}-10$ ( $\left.\delta_{\mathrm{c}} 102.7\right)$, and C-5a $\left(\delta_{\mathrm{c}} 101.3\right)$, of H-10 $\left(\delta_{\mathrm{H}} 6.70, \mathrm{~s}\right)$ to C-5a, C-4a $\left(\delta_{\mathrm{c}} 107.3\right), \mathrm{C}-9 \mathrm{a}$ and C-10a ( $\left.\delta_{\mathrm{C}} 140.1\right)$, of Me-8 to C-8 and C-9 ( $\left.\delta_{\mathrm{C}} 104.6\right)$, and of OH-5 ( $\left.\delta_{\mathrm{H}} 11.90\right)$ to C-5 ( $\left.\delta_{\mathrm{C}} 160.3\right)$, $\mathrm{C}-5 \mathrm{a}$ and $\mathrm{C}-4 \mathrm{a}$. Taking together the ${ }^{1} \mathrm{H}$ and ${ }^{13} \mathrm{C}$ chemical shift values and the COSY, HSQC and HMBC correlations (Table 1), the presence of $4 \mathrm{a}, 10 \mathrm{a}$-disubstituted-5-hydroxy-8-methylisochromen-6-one was corroborated. That the 5-hydroxy-8-methylisochromen-6-one nucleus was fused with a pyran-2-one moiety on C-4a and C-10a was substantiated by the HMBC correlations of $\mathrm{H}-4\left(\delta_{\mathrm{H}} 8.13, \mathrm{~d}, J=9.8 \mathrm{~Hz}\right)$ to $\mathrm{C}-10 \mathrm{a}\left(\delta_{\mathrm{C}} 140.1\right)$, and of $\mathrm{H}-3\left(\delta_{\mathrm{H}} 6.36, \mathrm{~d}, J=9.8 \mathrm{~Hz}\right)$ to $\mathrm{C}-4 \mathrm{a}\left(\delta_{\mathrm{C}} 107.3\right)$ and $\mathrm{C}-2\left(\delta_{\mathrm{C}} 159.7\right)$, 
respectively. Thus, the structure of compound $\mathbf{1}$ was established as 5-hydroxy-8-methyl-2H, $6 H$-pyrano[3,4-g]chromene-2,6-dione. To the best of our knowledge, this is the first report on the isolation of a secondary metabolite with both coumarin and isocoumarin functionalities in the same molecule. Thus, compound $\mathbf{1}$ is a new compound which we have named similanpyrone A.

Table 1. ${ }^{1} \mathrm{H}$ and ${ }^{13} \mathrm{C}$ NMR $\left(\mathrm{CDCl}_{3}, 500.13 \mathrm{MHz}\right.$ and $\left.125.8 \mathrm{MHz}\right)$ and $\mathrm{HMBC}$ assignment for similanpyrone A (1).

\begin{tabular}{ccccc}
\hline Position & $\boldsymbol{\delta}_{\mathbf{C}}$, Type & $\boldsymbol{\delta}_{\mathbf{H}},(\boldsymbol{J}$ in Hz) & COSY & HMBC \\
\hline 2 & $159.7, \mathrm{C}$ & - & & \\
3 & $114.1, \mathrm{CH}$ & $6.36, \mathrm{~d}(9.8)$ & $\mathrm{H}-4$ & $10 \mathrm{a}$ \\
4 & $137.8, \mathrm{CH}$ & $8.13, \mathrm{~d}(9.8)$ & $\mathrm{H}-3$ & $\mathrm{C}-2,4 \mathrm{a}$ \\
$4 \mathrm{a}$ & $107.3, \mathrm{C}$ & - & & \\
5 & $160.3, \mathrm{C}$ & - & & \\
$5 \mathrm{a}$ & $101.3, \mathrm{C}$ & - & & \\
6 & $166.3, \mathrm{C}$ & - & & \\
8 & $156.2, \mathrm{C}$ & - & & \\
9 & $104.6, \mathrm{CH}$ & $6.33, \mathrm{~s}$ & $\mathrm{CH}_{3}-8$ & $\mathrm{C}-5 \mathrm{a}, 8,10, \mathrm{Me}-8$ \\
$9 \mathrm{a}$ & $130.0, \mathrm{C}$ & - & & $\mathrm{C}-4 \mathrm{a}, 5 \mathrm{a}, 9 \mathrm{a}, 10 \mathrm{a}$ \\
10 & $102.7, \mathrm{CH}$ & $6.70, \mathrm{~s}$ & & \\
$10 \mathrm{a}$ & $140.1, \mathrm{C}$ & - & & $\mathrm{C}-8,9$ \\
$\mathrm{CH}_{3}-8$ & $19.6, \mathrm{CH} \mathrm{H}_{3}$ & $2.33, \mathrm{~s}$ & $\mathrm{H}-9$ & $\mathrm{C}-4 \mathrm{a}, 5,5 \mathrm{a}$ \\
$\mathrm{OH}^{-5}$ & - & $11.90, \mathrm{~s}$ & & \\
\hline
\end{tabular}

Compound $\mathbf{2 b}$ was also isolated as white solid (mp, $162-163{ }^{\circ} \mathrm{C}$ ), and its molecular formula $\mathrm{C}_{11} \mathrm{H}_{10} \mathrm{O}_{4}$ was established on the basis of the (+)-HRESIMS $m / z 207.0658[\mathrm{M}+\mathrm{H}]^{+}$, indicating seven degrees of unsaturation. The IR spectrum showed absorption bands for hydroxyl $\left(3243,3160 \mathrm{~cm}^{-1}\right)$, conjugated carbonyl $\left(1677 \mathrm{~cm}^{-1}\right)$, olefin $\left(1635 \mathrm{~cm}^{-1}\right)$ and aromatic $\left(1617 \mathrm{~cm}^{-1}\right)$ groups. The general feature of the ${ }^{1} \mathrm{H}$ (Supplementary Information, Figure S6), and ${ }^{13} \mathrm{C}$ NMR spectra (Supplementary Information, Figure S7) of $\mathbf{2 b}$ (Table 2) closely resembled those of $\mathbf{1}$, except for the absence of the proton and carbon signals of the pyran-2-one moiety. Instead, there were an additional methyl $\left(\delta_{\mathrm{H}} 2.00 \mathrm{~s} ; \delta_{\mathrm{C}} 8.0\right)$ and hydroxyl $\left(\delta_{\mathrm{H}}\right.$ 3.45 brs) groups in the structure of $\mathbf{2 b}$. That the second methyl group was on C-7 and the second hydroxyl group was on C-6 was corroborated by the HMBC cross peaks of the methyl singlet at $\delta_{\mathrm{H}} 2.20$, s to the signals of C-6 $\left(\delta_{\mathrm{C}} 163.7\right), \mathrm{C}-7\left(\delta_{\mathrm{C}} 109.6\right)$ and C-8 $\left(\delta_{\mathrm{C}} 106.9\right)$. Thus, the structure of compound $\mathbf{2 b}$ was established as 6, 8-dihydroxy-3, 7-dimethylisochromen-1-one. Literature survey revealed that $\mathbf{2 b}$ is a new compound, and therefore we have named it similanpyrone B.

Compound 3 was isolated as white crystals (mp, 262-263 ${ }^{\circ} \mathrm{C}$ ), and its molecular formula $\mathrm{C}_{26} \mathrm{H}_{38} \mathrm{O}_{4}$ was established on the basis of the (+)-HRESIMS $m / z 415.2851[\mathrm{M}+\mathrm{H}]^{+}$, indicating eight degrees of unsaturation. The IR spectrum showed absorption bands for hydroxyl $\left(3300 \mathrm{~cm}^{-1}\right)$, conjugated carbonyl $\left(1664 \mathrm{~cm}^{-1}\right)$ and olefin $\left(1607,1570 \mathrm{~cm}^{-1}\right)$ groups. The ${ }^{13} \mathrm{C}$ NMR (Supplementary Information, Figure S9), DEPTs and HSQC spectra revealed the presence of one conjugated ketone carbonyl $\left(\delta_{\mathrm{c}} 180.6\right)$, three quaternary $\mathrm{sp}^{2}\left(\delta_{\mathrm{c}} 162.6,160.5,98.5\right)$, one methine $\mathrm{sp}^{2}\left(\delta_{\mathrm{c}} 111.9\right)$, one oxygen bearing quaternary $\mathrm{sp}^{3}\left(\delta_{\mathrm{c}} 84.3\right)$, one oxygen bearing methine $\mathrm{sp}^{3}\left(\delta_{\mathrm{c}} 78.7\right)$, three quaternary $\mathrm{sp}^{3}\left(\delta_{\mathrm{c}} 37.1,37.3\right.$, $38.9)$, three methine $\mathrm{sp}^{3}\left(\delta_{\mathrm{C}} 52.3,55.3,60.3\right)$, seven methylene $\mathrm{sp}^{3}\left(\delta_{\mathrm{C}} 15.2,17.9,18.7,27.2,38.4,40.1\right.$, 
41.1) and six methyl $\left(\delta_{c} 15.4,16.1,16.4,19.2,20.5,28.0\right)$ carbons. The general feature of the ${ }^{1} \mathrm{H}$ (Supplementary Information, Figure S8), and ${ }^{13} \mathrm{C}$ NMR spectra of 3 resembled those of chevalone C [9], except for the chemical shift values of the oxygen bearing methine carbon (C-3) which appeared at lower frequencies $\left(\delta_{\mathrm{C}} 78.7 ; \delta_{\mathrm{H}} 3.21, \mathrm{dd}, J=11.1,5.0 \mathrm{~Hz}\right)$ than those of chevalone $\mathrm{C}$ [9]. Furthermore, the ${ }^{1} \mathrm{H}$ and ${ }^{13} \mathrm{C}$ NMR spectra of compound 3 did not exhibit the signals of the acetyl group. Taking together the IR, HRMS and NMR data, it was possible to conclude that compound $\mathbf{3}$ is a deacetyl analog of chevalone C. Since this is the first report of isolation of this chevalone analog, we have named it chevalone E. Final proof of the structure and the stereochemistry assigned to chevalone E (3) was provided by an X-ray analysis (Figure 2), and since the diffraction data were collected with a Gemini PX Ultra equipped with $\mathrm{CuK} \alpha$ radiation, it was possible to establish the absolute configuration of C-3, C-5, C-8, C-9, C-10, C-13 and C-14, respectively as $3 S, 5 R, 8 R, 9 R, 10 R, 13 S$ and $14 S$.

Table 2. ${ }^{1} \mathrm{H}$ and ${ }^{13} \mathrm{C}$ NMR $\left(\mathrm{CDCl}_{3}, 500.13 \mathrm{MHz}\right.$ and $\left.125.8 \mathrm{MHz}\right)$ and $\mathrm{HMBC}$ assignment for similanpyrone B (2b).

\begin{tabular}{ccccc}
\hline Position & $\boldsymbol{\delta}_{\mathbf{C}}$, Type & $\boldsymbol{\delta}_{\mathbf{H}},(\boldsymbol{J}$ in $\mathbf{H z})$ & $\mathbf{C O S Y}$ & HMBC \\
\hline 1 & $166.1, \mathrm{CO}$ & - & & \\
3 & $153.3, \mathrm{C}$ & - & & \\
4 & $104.2, \mathrm{CH}$ & $6.46, \mathrm{~s}$ & $\mathrm{CH}_{3}-3$ & $\mathrm{C}-5,8 \mathrm{a}$ \\
$4 \mathrm{a}$ & $136.5, \mathrm{C}$ & - & & \\
5 & $101.4, \mathrm{CH}$ & $6.40, \mathrm{~s}$ & & $\mathrm{C}-4,6,7,8 \mathrm{a}$ \\
6 & $163.7, \mathrm{C}$ & - & \\
7 & $109.6, \mathrm{C}$ & - & \\
8 & $160.0, \mathrm{C}$ & - & \\
$8 \mathrm{a}$ & $97.5, \mathrm{C}$ & - & $\mathrm{C}-3,4$ \\
$\mathrm{CH}_{3}-3$ & $18.8, \mathrm{CH} 3$ & $2.20, \mathrm{~s}$ & & \\
$\mathrm{CH}_{3}-7$ & $8.0, \mathrm{CH}$ & $2.00, \mathrm{~s}$ & & \\
$\mathrm{OH}_{3}-6$ & - & $3.45, \mathrm{br}$ & & \\
$\mathrm{OH}-8$ & - & $11.27, \mathrm{~s}$ & & \\
\hline
\end{tabular}

Figure 2. Ortep view of chevalone E (3).

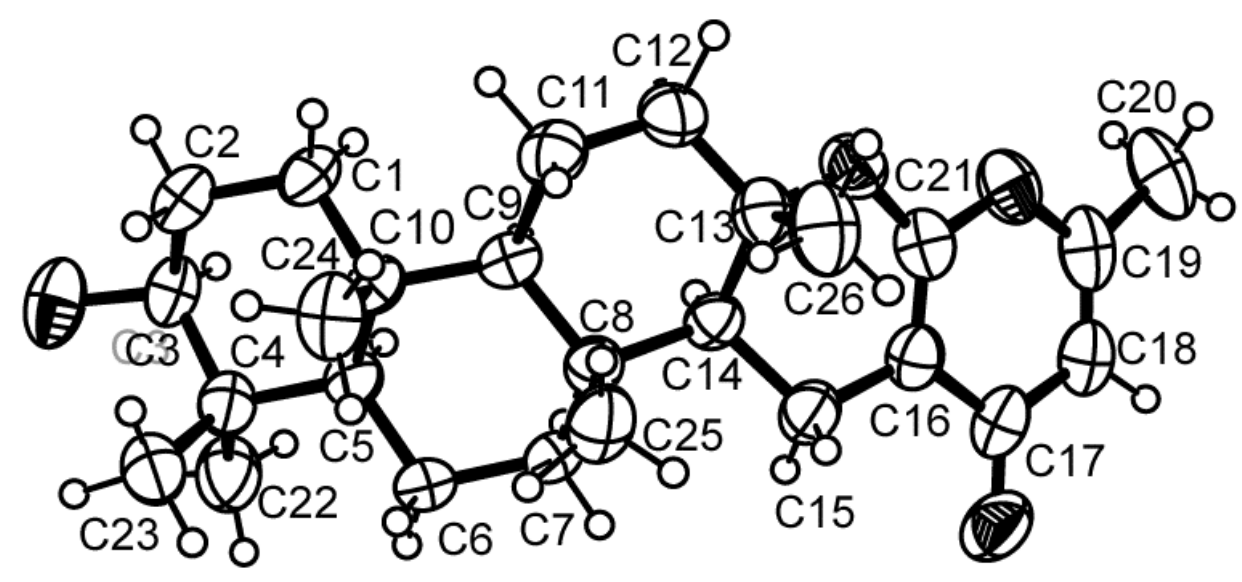


The (+)-HRESIMS of compound 6 indicated the $[\mathrm{M}+\mathrm{H}]^{+}$peak at $\mathrm{m} / \mathrm{z} 566.2416$, corresponding to $\mathrm{C}_{31} \mathrm{H}_{36} \mathrm{NO} 9$. Thus, the molecular formula of compound 6 was $\mathrm{C}_{31} \mathrm{H}_{35} \mathrm{NO}$, indicating fifteen degrees of unsaturation. The IR spectrum showed absorption bands for ester carbonyl $\left(1742 \mathrm{~cm}^{-1}\right)$, conjugated carbonyl $\left(1671 \mathrm{~cm}^{-1}\right)$, aromatic $\left(1586,1508,1465 \mathrm{~cm}^{-1}\right)$ and olefin $\left(1625 \mathrm{~cm}^{-1}\right)$ groups. The ${ }^{13} \mathrm{C} \mathrm{NMR}$ (Supplementary Information, Figure S11), DEPTs and HSQC spectra (Table 3) revealed the presence of three ester carbonyls $\left(\delta_{\mathrm{C}} 171.0,170.4,169.8\right)$, one conjugated carbonyl $\left(\delta_{\mathrm{C}} 161.3\right)$, five quaternary sp ${ }^{2}$ $\left(\delta_{\mathrm{C}} 161.2,157.2,144.5,127.4,101.1\right)$, six methine $\mathrm{sp}^{2}\left(\delta_{\mathrm{C}} 152.1,146.6,133.1,123.8,111.2,98.6\right)$, one oxyquaternary $\mathrm{sp}^{3}\left(\delta_{\mathrm{C}} 83.9\right)$, two oxymethine $\mathrm{sp}^{3}\left(\delta_{\mathrm{C}} 77.7\right.$ and 73.2$)$, one oxymethylene $\mathrm{sp}^{3}\left(\delta_{\mathrm{C}} 64.7\right)$, two quaternary $\mathrm{sp}^{3}\left(\delta_{\mathrm{C}} 40.6\right.$ and 38.8$)$, one methine $\mathrm{sp}^{3}\left(\delta_{\mathrm{C}} 41.1\right)$, three methylene $\mathrm{sp}^{3}\left(\delta_{\mathrm{C}} 35.5,24.3\right.$ and 23.2), and six methyl ( $\delta_{\mathrm{C}} 24.2,21.3,21.2,21.2,20.8$ and 13.3) carbons. Analysis of the ${ }^{1} \mathrm{H}$ (Supplementary Information, Figure $\mathrm{S} 10$ ), ${ }^{13} \mathrm{C}$, HSQC and $\mathrm{HMBC}$ spectra (Table 3) revealed the presence of, besides three acetoxyl groups $\left(\delta_{\mathrm{C}} 170.4,21.2, \delta_{\mathrm{H}} 2.05 \mathrm{~s} ; \delta_{\mathrm{C}} 171.0,20.8, \delta_{\mathrm{H}} 2.10 \mathrm{~s} ; \delta_{\mathrm{C}} 169.8\right.$, $\left.21.2, \delta_{\mathrm{H}} 2.17, \mathrm{~s}\right)$, a hexasubstituted decahydronaphthalene ring system. That two of the acetoxyl groups were on $\mathrm{C}-1$ and $\mathrm{C}-7$, and the three methyl groups were on $\mathrm{C}-4, \mathrm{C}-6$ and $\mathrm{C}-10$ of the decahydronaphthalene moiety was substantiated by the HMBC cross peaks of the Me- 15 singlet $\left(\delta_{\mathrm{H}} 0.88, \mathrm{~s}\right)$ to the carbon signals at $\delta_{\mathrm{C}} 40.6(\mathrm{C}-10), 72.2(\mathrm{C}-1), 64.7(\mathrm{C}-11)$, of the Me-12 singlet $\left(\delta_{\mathrm{H}} 1.26, \mathrm{~s}\right)$ to the carbon signals at $\delta_{\mathrm{C}} 35.5(\mathrm{C}-3), 38.8(\mathrm{C}-4), 41.1(\mathrm{C}-9)$, and of the Me-14 singlet $\left(\delta_{\mathrm{H}} 1.59\right.$, s) to the carbon signals at $\delta_{\mathrm{C}} 77.7(\mathrm{C}-7), 83.9(\mathrm{C}-6)$, and $144.5(\mathrm{C}-5)$. That another substituent on $\mathrm{C}-10$ was the acetoxymethylene group was evidenced by the $\mathrm{HMBC}$ cross peaks of $\mathrm{H}-11$ signals $\left(\delta_{\mathrm{H}} 3.75, \mathrm{~d}, J=11.9 \mathrm{~Hz}\right.$; $3.79, \mathrm{~d}, J=11.9 \mathrm{~Hz}$ ) to $\mathrm{C}-1, \mathrm{C}-9$, and the signal of the carbonyl at $\delta_{\mathrm{C}} 171.0$. On the other hand, since Me-14 singlet gave cross peaks to the signals of the oxyquaternary carbon at $\delta_{\mathrm{C}} 83.9(\mathrm{C}-6)$ and the quaternary sp ${ }^{2}$ carbon at $\delta_{\mathrm{C}} 144.5$ (C-5), the double bond was on C-5, and C-6 was oxygen bearing. This was corroborated by the HMBC cross peaks of the signal of the olefinic proton at $\delta_{\mathrm{H}} 6.36, \mathrm{~s}(\mathrm{H}-13)$ to C-4 and C-6. Moreover, the HMBC spectrum also exhibited a cross peak of H-13 signal to the signals of a conjugated carbonyl carbon at $\delta_{\mathrm{C}} 161.3\left(\mathrm{C}-2^{\prime}\right)$ and the quaternary $\mathrm{sp}^{2}$ carbon at $\delta_{\mathrm{C}} 161.2\left(\mathrm{C}-4^{\prime}\right)$. On the other hand, there were also HMBC cross peaks of another olefinic proton at $\delta_{\mathrm{H}} 6.54, \mathrm{~s}\left(\mathrm{H}-5^{\prime}\right)$ to $\mathrm{C}-4^{\prime}$ and the signals of another two quaternary sp ${ }^{2}$ carbon at $\delta \mathrm{C} 101.1\left(\mathrm{C}-3^{\prime}\right)$ and $157.2\left(\mathrm{C}-6^{\prime}\right)$. Taken together the HMBC correlations, it was clear that the decahydronaphthalene ring system was fused, on $\mathrm{C}-5$ and C-6, with 2H, 5H-pyrano[4, 3-b]pyran-5-one ring system. The COSY and HMBC spectra also indicated the presence of the 3 -substituted pyridine ring. That this pyridine ring was connected to the pyranone ring through $\mathrm{C}-3$ of the former and C- $6^{\prime}$ of the later was evidenced by the HMBC correlations of the $\mathrm{H}-5^{\prime}$ singlet to C-3" ( $\left.\delta_{\mathrm{C}} 127.4\right)$, as well as of the signal of $\mathrm{H}-2^{\prime \prime}\left(\delta_{\mathrm{H}} 8.14\right.$, dt, $\left.J=7.8,2.4,2.4 \mathrm{~Hz}\right)$ to C-6'. Literature search revealed that compound $\mathbf{6}$ was previously obtained by treatment of pyripyropene A with $\mathrm{HCl}$ under anhydrous condition [15]; however, there were neither reports of the ${ }^{1} \mathrm{H}$ and ${ }^{13} \mathrm{C}$ data nor other description of this compound. Since 6 is a new natural product, we have named it pyripyropene S. It is interesting to point out that $\mathbf{6}$ is the first natural pyripyropene that lacks a hydroxyl group on C-13. 
Table 3. ${ }^{1} \mathrm{H}$ and ${ }^{13} \mathrm{C} \mathrm{NMR}\left(\mathrm{CDCl}_{3}, 500.13 \mathrm{MHz}\right.$ and $\left.125.8 \mathrm{MHz}\right)$ and $\mathrm{HMBC}$ assignment for pyripyropene $\mathrm{S}(\mathbf{6})$.

\begin{tabular}{|c|c|c|c|c|}
\hline Position & $\delta_{\mathrm{C}}$, Type & $\delta_{\mathrm{H}},(J$ in $\mathbf{H z})$ & COSY & HMBC \\
\hline 1 & $73.2, \mathrm{CH}$ & $4.79, \mathrm{dd}(11.7,4.6)$ & $\mathrm{H}-2$ & \\
\hline 2 & 23.2, $\mathrm{CH}_{2}$ & $\begin{array}{l}1.99, \mathrm{~m} \\
1.76, \mathrm{~m}\end{array}$ & H-1 & \\
\hline 3 & $35.5, \mathrm{CH}_{2}$ & $2.09, \mathrm{~m}$ & $\mathrm{H}-2$ & \\
\hline 4 & $38.8, \mathrm{C}$ & - & & \\
\hline 5 & $144.5, \mathrm{C}$ & - & & \\
\hline 6 & $83.9, \mathrm{C}$ & - & & \\
\hline 7 & $77.7, \mathrm{CH}$ & $5.23, \mathrm{dd}(11.9,5.4)$ & H-8 & C-6 \\
\hline 8 & $24.3, \mathrm{CH}_{2}$ & $\begin{array}{c}1.82, \text { ddd }(12.8,5.1,1.4) \\
1.61, \mathrm{~m}\end{array}$ & H-7, H-9 & \\
\hline 9 & $41.1, \mathrm{CH}$ & 1.73, brd $(12.5)$ & H-8 & \\
\hline 10 & $40.6, \mathrm{C}$ & - & & \\
\hline 11 & 64.7, $\mathrm{CH}_{2}$ & $\begin{array}{l}3.75, \mathrm{~d}(11.9) \\
3.79, \mathrm{~d}(11.9)\end{array}$ & & $\mathrm{C}-1,9, \mathrm{CO}(\mathrm{OAc}-11)$ \\
\hline 12 & $24.2, \mathrm{CH}_{3}$ & $1.26, \mathrm{~s}$ & & C- $3,4,9$ \\
\hline 13 & $111.2, \mathrm{CH}$ & $6.36, \mathrm{~s}$ & & $\mathrm{C}-4,6,4^{\prime}$ \\
\hline 14 & 21.3, $\mathrm{CH}_{3}$ & $1.59, \mathrm{~s}$ & & $\mathrm{C}-5,6,7$ \\
\hline 15 & $13.3, \mathrm{CH}_{3}$ & $0.88, \mathrm{~s}$ & & $\mathrm{C}-1,10,11$ \\
\hline $2^{\prime}$ & 161.3, C & - & & \\
\hline $3^{\prime}$ & 101.1, C & - & & \\
\hline $4^{\prime}$ & 161.2, C & - & & \\
\hline $5^{\prime}$ & $98.6, \mathrm{CH}$ & $6.54, \mathrm{~s}$ & & $\mathrm{C}-2^{\prime}, 3^{\prime}, 6^{\prime}, 3^{\prime \prime}$ \\
\hline $6^{\prime}$ & $157.2, \mathrm{C}$ & - & & \\
\hline $2^{\prime \prime}$ & 146.6, CH & 9.02, brs & $\mathrm{H}-4^{\prime \prime}$ & C-3", 4", 6" \\
\hline $3 "$ & $127.4, \mathrm{C}$ & - & & \\
\hline $4^{\prime \prime}$ & $133.1, \mathrm{CH}$ & $8.14, \mathrm{dt}(7.8,1.4,1.4)$ & $\mathrm{H}-2^{\prime \prime}, 5^{\prime \prime}$ & $\mathrm{C}-6^{\prime}, 2^{\prime \prime}, 6^{\prime \prime}$ \\
\hline $5^{\prime \prime}$ & $123.8, \mathrm{CH}$ & $7.42, \mathrm{dd}(8.0,4.9)$ & H-4", 6" & C-3", 6" \\
\hline $6^{\prime \prime}$ & $151.2, \mathrm{CH}$ & 8.68, brd (4.0) & H-5" & C-5" \\
\hline OAc-1 & $\begin{array}{l}170.4, \mathrm{CO} \\
21.2, \mathrm{CH}_{3}\end{array}$ & $\begin{array}{c}- \\
2.05, \mathrm{~s}\end{array}$ & & $\mathrm{CO}(\mathrm{OAc}-1)$ \\
\hline OAc-7 & $\begin{array}{l}169.8, \mathrm{CO} \\
21.2, \mathrm{CH}_{3}\end{array}$ & $\begin{array}{c}- \\
2.17, \mathrm{~s}\end{array}$ & & $\mathrm{CO}(\mathrm{OAc}-7)$ \\
\hline OAc-11 & $\begin{array}{l}171.0, \mathrm{CO} \\
20.8, \mathrm{CH}_{3}\end{array}$ & $\begin{array}{c}- \\
2.10, \mathrm{~s} \\
\end{array}$ & & $\mathrm{CO}(\mathrm{OAc}-11)$ \\
\hline
\end{tabular}

Compounds 1, 2a-c and 3-6 were tested for their antimicrobial activity against Gram positive (Staphylococcus aureus ATCC 25923 and Bacillus subtilis ATCC 6633) and Gram negative (Escherichia coli ATCC 25922 and Pseudomonas aeruginosa ATCC 27853) bacteria, Candida albicans ATCC 10231, and multidrug-resistant isolates from the environment. All the compounds tested exhibited neither antibacterial nor antifungal activities, i.e., their MIC values were found to be higher than $256 \mu \mathrm{g} / \mathrm{mL}$. Like chevalone $\mathrm{C}$, chevalone $\mathrm{E}$ (3) does not possess the structural requirements for the antibacterial activity of this group of meroditerpenes, i.e., the presence of the $\beta$-acetoxyl group on C-3 and the presence of a free 4-hydroxy-6-methyl-2H-pyran-2-one ring on C-15 [9]. Therefore, it is not 
surprising that chevalone E (3) did not exhibit significant antibacterial activity. The fact that chevalone $\mathrm{C}$ did not show significant antibacterial activity but demonstrated synergistic effect with the antibiotics against three multidrug-resistant isolates [9] led us explore if some of these compounds could possibly have synergistic effects with antibiotics, i.e., by using a disc diffusion method to assess if, in combination with antibiotics, they could cause an increase in the growth inhibition of multidrug-resistant strains. The results (Table 4) showed that no synergistic effects were observed between the tested compounds and antibiotics for multidrug-resistant E. coli and E. faecalis; however chevalone E (3) was found to exhibit potential synergy with oxacillin and ampicillin against the MRSA strain.

Table 4. Antibacterial efficacy of combined effect of antibiotics with the compounds $(15 \mu \mathrm{g} /$ disc) against three multidrug-resistant isolates, using the disc diffusion method.

\begin{tabular}{|c|c|c|c|c|c|c|c|c|c|c|}
\hline \multirow{3}{*}{ Compound } & \multicolumn{4}{|c|}{ E. coli G1 } & \multicolumn{3}{|c|}{ S. aureus B1 } & \multicolumn{3}{|c|}{ E. faecalis W1 } \\
\hline & \multicolumn{10}{|c|}{ Antibiotics } \\
\hline & CIP & AMP & CTX & $\mathbf{S}$ & OX & AMP & CIP & VA & AMP & $\mathbf{E}$ \\
\hline 1 & - & - & - & - & - & - & - & - & - & - \\
\hline $2 a$ & - & - & - & - & - & ++ & - & - & - & - \\
\hline $2 b$ & - & - & - & - & - & ++ & - & - & - & - \\
\hline $2 c$ & & & & - & - & ++ & - & - & - & - \\
\hline 3 & - & - & - & - & +++ & +++ & - & - & - & - \\
\hline 4 & & & - & - & & ++ & - & - & - & - \\
\hline 5 & - & - & - & - & - & ++ & - & - & - & - \\
\hline 6 & - & - & - & - & - & ++ & - & - & - & - \\
\hline
\end{tabular}

$(-)$ noneffective; $(+)$ slight efficacy - halo of inhibition or additional increase in the halo of 1 to $2.5 \mathrm{~mm}$ around the disc; (++) moderate efficacy-from $>2.5$ to $5 \mathrm{~mm} ;(+++) \operatorname{good}$ efficacy-from $>5$ to $8 \mathrm{~mm}$; CIP: ciprofloxacin; AMP: ampicillin; CTX: cefotaxime; S: streptomycin; OX: oxacillin; VA: vancomycin; E: Erythromycin.

In order to verify if the synergism occurred with both antibiotics or with either of them, the checkerboard method was carried out. The results, represented by the fractional inhibitory concentration (FIC) index, shown in Table 5, confirmed the synergy between chevalone E (3) and oxacillin, and not between chevalone E (3) and ampicillin. It is interesting to note that while chevalone E (3) shows synergism with oxacillin against the MRSA isolate, the structurally related meroditerpene aszonapyrone exhibited synergism only with vancomycin against the VRE isolate, and not with oxacillin against the MRSA strain [9].

Table 5. MIC values of chevalone E (3) in combination with oxacillin or ampicillin, and the respective FIC index obtained against a MRSA (S. aureus B1) using the checkerboard method.

\begin{tabular}{cccccc}
\hline Strain & \multicolumn{5}{c}{ MIC $(\boldsymbol{\mu g} / \mathbf{m L})$} \\
\hline \multirow{2}{*}{ S. aureus $\mathrm{B} 1$} & $\mathbf{3}$ alone & OX alone & $\mathbf{3}$ with OX & OX with $\mathbf{3}$ & FIC index \\
& $>1024$ & 128 & 64 & 16 & $<0.188 *$ \\
\hline \multirow{2}{*}{ S. aureus $\mathrm{B} 1$} & $\mathbf{3}$ alone & AMP alone & $\mathbf{3}$ with AMP & AMP with $\mathbf{3}$ & FIC index \\
& $>1024$ & 128 & $>512$ & 128 & $>1.5$ \\
\hline
\end{tabular}

* FIC index $<0.5$ indicates synergy. 


\section{Experimental Section}

\subsection{General Procedures}

Melting points were determined on a Bock monoscope and are uncorrected. Optical rotations were determined on an ADP410 Polarimeter (Bellingham + Syanley Ltd., Tunbridge Wells, Kent, UK). Infrared spectra were recorded on an ATT Mattson Genesis Series FTIR ${ }^{\text {TM }}$ using WinFIRST Software. ${ }^{1} \mathrm{H}$ and ${ }^{13} \mathrm{C}$ NMR spectra were recorded at ambient temperature on a Bruker AMC instrument (Bruker Biosciences Corporation, Billerica, MA, USA) operating at 500.13 and $125.8 \mathrm{MHz}$, respectively. High resolution mass spectra were measured with a Waters Xevo QToF mass spectrometer (Waters Corporations, Milford, MA, USA) coupled to a Waters Aquity UPLC system. A Merck silica gel $\mathrm{GF}_{254}$ was used for preparative TLC, and a Merck Si gel $60(0.2-0.5 \mathrm{~mm})$ was used for analytical chromatography.

\subsection{Extraction and Isolation}

The strain KUFA0013 was isolated from the marine sponge Rhabdermia sp., which was collected from the coral reef of the Similan Islands, Phang Nga Province, Thailand, by scuba diving at $10 \mathrm{~m}$ depth, in April 2010, and the sponge was identified by J. Buaruang (Division of Environmental Science, Faculty of Science, Ramkhamhaeng University, Bangkok 10240, Thailand). Briefly, after rinsing with sterile sea water, the sponge was dried on sterile filter paper and cut into small pieces $(5 \times 5 \mathrm{~mm})$ and placed on the plates containing malt extract agar [MEA, $30 \mathrm{~g}$ of malt extract powder (Himedia, Mumbai, India), $15 \mathrm{~g}$ of bacto agar, distilled water $300 \mathrm{~mL}$, sea water $700 \mathrm{~mL}$ and adjusted to the final $\mathrm{pH}$ at 5.5] with $70 \%$ sea water and incubated at $28^{\circ} \mathrm{C}$ under $12 \mathrm{~h} \mathrm{light} / 12 \mathrm{~h}$ dark cycle for seven days. The fungus was identified by one of us (T. Dethoup), by morphological features, including characteristic of ascospores, conidiogenesis and colonies, as well as by DNA sequence analysis of the calmodulin gene described by the previous report [16] (GenBank Accession No. KC 920702). Since the sequence was not identical to that deposited at GenBank, the strain was not identified at species level. The pure cultures were deposited as KUFA0013 at the Department of Plant Pathology, Faculty of Agriculture, Kasetsart University, Bangkok, Thailand. A. similanensis (KUFA 0013) was cultured for one week in five $90 \mathrm{~mm}$ Petri dishes (i.d. $90 \mathrm{~mm}$ ) containing $25 \mathrm{~mL}$ of MEA with $70 \%$ sea water per dish. Thirty $1000 \mathrm{~mL}$ Erlenmeyer flasks, each containing white rice $(200 \mathrm{~g})$, water $(30 \mathrm{~mL})$ and sea water $(70 \mathrm{~mL})$, were autoclaved at $121^{\circ} \mathrm{C}$ for $15 \mathrm{~min}$, inoculated with ten mycelia plugs of the fungus and incubated at $28^{\circ} \mathrm{C}$ for 30 days. The moldy rice was macerated in ethyl acetate $(7 \mathrm{~L}$ total) for seven days and then filtered by filter paper. The two layers were separated using a separatory funnel, and the ethyl acetate solution was evaporated under reduced pressure to yield $97 \mathrm{~g}$ of crude ethyl acetate extract that was dissolved in $500 \mathrm{~mL}$ of a 4:1 mixture of EtOAc and $\mathrm{CHCl}_{3}$, and then washed with $5 \% \mathrm{NaHCO}_{3}$ aqueous solution $(2 \times 300 \mathrm{~mL})$ and $\mathrm{H}_{2} \mathrm{O}(3 \times 300 \mathrm{~mL})$. The organic layer was dried with anhydrous $\mathrm{Na}_{2} \mathrm{SO}_{4}$, filtered and evaporated under reduced pressure to give $75 \mathrm{~g}$ of crude extract, which was applied on a column chromatography of silica gel $(640 \mathrm{~g})$ and eluted with mixtures of $\mathrm{CHCl}_{3}$-petrol and $\mathrm{CHCl}_{3}-\mathrm{Me}_{2} \mathrm{CO}, 250 \mathrm{~mL}$ fractions were collected as follows: Frs 1-18 $\left(\mathrm{CHCl}_{3}-\right.$ petrol, 3:7), 19-53 $\left(\mathrm{CHCl}_{3}-\right.$ petrol, 1:1), 54-114 $\left(\mathrm{CHCl}_{3}-\right.$ petrol, 7:3), 115-215 ( $\mathrm{CHCl}_{3}-$ petrol, 9:1), 216-395 $\left(\mathrm{CHCl}_{3}-\mathrm{Me}_{2} \mathrm{CO}, 9: 1\right), 396-443\left(\mathrm{CHCl}_{3}-\mathrm{Me}_{2} \mathrm{CO}, 7: 3\right)$. Frs 185-196 were combined (654 mg) and purified by TLC (Si gel, $\left.\mathrm{CHCl}_{3}: \mathrm{Me}_{2} \mathrm{CO}: \mathrm{HCO}_{2} \mathrm{H}, 97: 3: 0.01\right)$ to 
give $4 \mathrm{mg}$ of 1 . Frs $197-221$ were combined $(1.16 \mathrm{~g})$ and crystallized in a mixture of petrol and $\mathrm{CHCl}_{3}$ to give additional $107.6 \mathrm{mg}$ of yellow solid which was further purified by TLC (Si gel, $\left.\mathrm{CHCl}_{3}: \mathrm{Me}_{2} \mathrm{CO}: \mathrm{HCO}_{2} \mathrm{H}, 98: 2: 0.01\right)$ to give $2.5 \mathrm{mg}$ of 1 . Fr $222(8.06 \mathrm{~g})$ was recrystallized in a mixture of $\mathrm{CHCl}_{3}$ and $\mathrm{Me}_{2} \mathrm{CO}$ to give $238 \mathrm{mg}$ of white precipitate, which was further purified by TLC (Si gel, $\left.\mathrm{CHCl}_{3}: \mathrm{Me}_{2} \mathrm{CO}: \mathrm{HCO}_{2} \mathrm{H}, 97: 3: 0.01\right)$ to give $2 \mathbf{b}(32.7 \mathrm{mg}), 4(4.6 \mathrm{mg})$ and chevalone $\mathrm{B}(4.6 \mathrm{mg})$. The mother liquor was further purified by TLC ( $\mathrm{Si}$ gel, $\mathrm{CHCl}_{3}: \mathrm{Me}_{2} \mathrm{CO}: \mathrm{HCO}_{2} \mathrm{H}, 97: 3: 0.01$ ) to give $\mathbf{2 b}(41.0 \mathrm{mg}$ ), 4 (7.2 mg) and chevalone B (70.8 mg). The mother liquor of frs 197-221 and fr 222, and frs 223-224 were combined ( $9.18 \mathrm{~g}$ ), applied on the Si gel column ( $58 \mathrm{~g}$ ), and eluted with mixtures of petrol- $\mathrm{CHCl}_{3}$ and $\mathrm{CHCl}_{3}-\mathrm{Me}_{2} \mathrm{CO}$, wherein $100 \mathrm{~mL}$ sfrs were collected as follows: sfrs 1-59 (petrol- $\mathrm{CHCl}_{3}, 3: 7$ ), 60-69 (petrol- $\left.\mathrm{CHCl}_{3}, 1: 9\right), 70-76\left(\mathrm{CHCl}_{3}-\mathrm{Me}_{2} \mathrm{CO}, 9: 1\right)$. Sfrs 11-22 were combined (1.97 g) and crystallized in a mixture of petrol and $\mathrm{CHCl}_{3}$ to give additional $16.4 \mathrm{mg}$ of $\mathbf{1}$. Sfrs $29-42$ were combined (468 $\mathrm{mg}$ ) and crystallized in a mixture of petrol and $\mathrm{CHCl}_{3}$ to give additional $92.1 \mathrm{mg}$ of $\mathbf{2 b}$. Frs 225-228 were combined $\left(446 \mathrm{mg}\right.$ ) and crystallized in a mixture of petrol and $\mathrm{CHCl}_{3}$ to give $63 \mathrm{mg}$ of a precipitate which was further purified by TLC ( $\mathrm{Si}$ gel, $\mathrm{CHCl}_{3}: \mathrm{Me}_{2} \mathrm{CO}: \mathrm{HCO}_{2} \mathrm{H}, 97: 3: 0.01$ ) to give $\mathbf{2 b}$ (35.8 $\mathrm{mg}$ ) and 2a (35.4 mg). The mother liquor of frs 225-228 and frs 229-330 were combined and chromatographed on a Si gel column (33 g) and eluted with mixtures of petrol- $\mathrm{CHCl}_{3}$ and $\mathrm{CHCl}_{3}-\mathrm{Me}_{2} \mathrm{CO}$, wherein $100 \mathrm{~mL}$ sub-fractions were collected as follows: sfrs 1-49 (petrol- $\mathrm{CHCl}_{3}, 3: 7$ ), 50-64 (petrol- $\mathrm{CHCl}_{3}, 1: 9$ ), 65-77 $\left(\mathrm{CHCl}_{3}-\mathrm{Me}_{2} \mathrm{CO}, 9: 1\right)$. Subfrs 4-5 were combined and recrystallized in a mixture of petrol and $\mathrm{CHCl}_{3}$ to give $1(2.4 \mathrm{mg})$. Sfrs $6-10$ were combined $(160 \mathrm{mg})$ and recrystallized in a mixture of petrol and $\mathrm{CHCl}_{3}$ to give $2 \mathrm{c}(7.6 \mathrm{mg})$. Sfrs 11-16 were combined (108 $\mathrm{mg})$ and recrystallized in a mixture of petrol to give 2b (5 mg). Sfrs 27-33 were combined (206 mg) and purified by TLC (Si gel, $\left.\mathrm{CHCl}_{3}: \mathrm{Me}_{2} \mathrm{CO} .93: 7\right)$ to give $p$-hydroxybenzaldehyde (36 mg). Frs 231-247 were combined $(6.7 \mathrm{~g})$ and recrystallized in a mixture of petrol and $\mathrm{Me}_{2} \mathrm{CO}$ to give $1.39 \mathrm{~g}$ of chevalone C. Frs 272-294 were combined (1.54 g) and crystallized in a mixture of petrol and $\mathrm{Me}_{2} \mathrm{CO}$ to yield 5 (265 mg). Frs 328-335 were combined (296 mg) and applied on a column of Sephadex LH-20 (22 g) and eluted with a mixture of $\mathrm{CHCl}_{3}-\mathrm{MeOH}$ (9:1) to give 3 (11.2 mg). Frs 354-398 were combined (1.14 g) and purified by TLC (Si gel, $\left.\mathrm{CHCl}_{3}: \mathrm{MeOH}: \mathrm{HCO}_{2} \mathrm{H}, 95: 5: 0.01\right)$ to give $6(27.3 \mathrm{mg})$.

\subsubsection{Similanpyrone A (1)}

White solid, Mp 322-323 ${ }^{\circ} \mathrm{C}$ (petrol/CHCl 3$) ; \mathrm{UV}\left(\mathrm{CHCl}_{3}\right) \lambda_{\max }(\log \varepsilon) 240$ (4.31), 269 (4.31), 295 (3.95), 333 (4.23), 358 (4.16) nm; IR (KBr) $v_{\max }$ 3446, 3010, 2923, 2851, 1748, 1698, 1658, 1634, 1464, 1177, $1151 \mathrm{~cm}^{-1} ;{ }^{1} \mathrm{H}$ and ${ }^{13} \mathrm{C}$ NMR (Table 1); HRESIMS $m / z 245.0455(\mathrm{M}+\mathrm{H})^{+}$(calculated for $\left.\mathrm{C}_{13} \mathrm{H}_{9} \mathrm{O}_{5}, 245.0450\right)$.

\subsubsection{Similanpyrone B (2b)}

White crystals, $\mathrm{Mp} 162-163{ }^{\circ} \mathrm{C}\left(\mathrm{petrol} / \mathrm{CHCl}_{3}\right) ; \mathrm{UV}\left(\mathrm{CHCl}_{3}\right) \lambda_{\max }(\log \varepsilon) 240$ (4.35), 277 (3.51), 330 (3.46) nm; IR (KBr) v $v_{\max } 3243,3160,2923,2851,1677,1634,1617,1585,1571,1455,1256,1154$, $1110 \mathrm{~cm}^{-1}$; ${ }^{1} \mathrm{H}$ and ${ }^{13} \mathrm{C}$ NMR (Table 2); HRESIMS $\mathrm{m} / z 207.0658(\mathrm{M}+\mathrm{H})^{+}$(calculated for $\left.\mathrm{C}_{11} \mathrm{H}_{11} \mathrm{O}_{4}, 207.0657\right)$. 


\subsubsection{Chevalone E (3)}

White crystals, $\mathrm{Mp} 262-263{ }^{\circ} \mathrm{C}\left(\right.$ petrol $\left./ \mathrm{CHCl}_{3}\right) ;[\alpha]_{\mathrm{D}}{ }^{20}-146.3^{\circ}\left(c 0.04, \mathrm{CHCl}_{3}\right)$; IR $(\mathrm{KBr}) v_{\max } 3300$, 3016, 2979, 2950, 2871, 1664, 1607, 1570, 1444, $1288 \mathrm{~cm}^{-1} ;{ }^{1} \mathrm{H} \mathrm{NMR}\left(\mathrm{CDCl}_{3}, 500.13 \mathrm{MHz}\right) \delta 5.99$ (1H, s, H-18), 3.21 (1H, d, $J=11.1,5.0, \mathrm{H}-3), 2.55$ (1H, dd, $\left.J=16.4,4.9, \mathrm{H}_{2}-15\right), 2.20$ (3H, s, H3-20), $2.15\left(1 \mathrm{H}, \mathrm{m}, \mathrm{H}_{2}-15\right), 2.14\left(1 \mathrm{H}, \mathrm{m}, \mathrm{H}_{2}-12\right), 1.90\left(1 \mathrm{H}, \mathrm{dt}, J=12.8,3, \mathrm{H}_{2}-7\right), 1.74\left(1 \mathrm{H}, \mathrm{m}, \mathrm{H}_{2}-11\right), 1.73$ $\left(1 \mathrm{H}, \mathrm{m}, \mathrm{H}_{2}-1\right), 1.71\left(1 \mathrm{H}, \mathrm{m}, \mathrm{H}_{2}-12\right), 1.64\left(2 \mathrm{H}, \mathrm{m}, \mathrm{H}_{2}-2\right), 1.59\left(1 \mathrm{H}, \mathrm{m}, \mathrm{H}_{2}-6\right), 1.50(1 \mathrm{H}, \mathrm{dd}$, $J=12.5,4.7, \mathrm{H}-14), 1.45$ (1H, m, H2-6), 1.36 (1H, m, $\left.\mathrm{H}_{2}-11\right), 1.28\left(3 \mathrm{H}, \mathrm{s}, \mathrm{H}_{3}-26\right), 1.05$ (1H, m, $\left.\mathrm{H}_{2}-7\right)$, $1.00\left(1 \mathrm{H}, \mathrm{m}, \mathrm{H}_{2}-1\right), 0.98$ (3H, s, H3-23), 0.93 (1H, brd, $\left.J=13.2, \mathrm{H}-9\right), 0.89$ (3H, s, H3-25), 0.84 (3H, s,

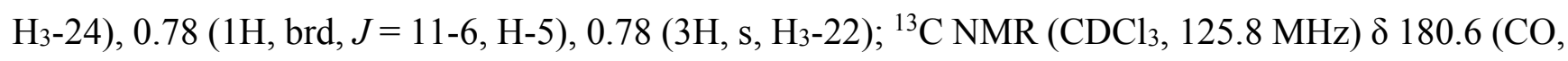
C-17), 162 (C, C-16), 160.5 (C, C-21), 111.9 (CH, C-18), 98.5 (C, C-19), 84.3 (C, C-13), 78.7 (CH, C-3), 60.3 (CH, C-9), 55.3 (CH, C-5), $52.3(\mathrm{CH}, \mathrm{C}-14), 41.1\left(\mathrm{CH}_{2}, \mathrm{C}-7\right), 40.1\left(\mathrm{CH}_{2}, \mathrm{C}-12\right), 38.9(\mathrm{C}, \mathrm{C}-4)$, $38.4\left(\mathrm{CH}_{2}, \mathrm{C}-1\right), 37.3(\mathrm{C}, \mathrm{C}-8), 37.1(\mathrm{C}, \mathrm{C}-10), 28.0\left(\mathrm{CH}_{3}, \mathrm{C}-23\right), 27.2\left(\mathrm{CH}_{2}, \mathrm{C}-2\right), 20.5\left(\mathrm{CH}_{3}, \mathrm{C}-26\right)$, $19.2\left(\mathrm{CH}_{3}, \mathrm{C}-20\right), 18.7\left(\mathrm{CH}_{2}, \mathrm{C}-11\right), 17.9\left(\mathrm{CH}_{2}, \mathrm{C}-6\right), 16.4\left(\mathrm{CH}_{3}, \mathrm{C}-24\right), 16.1\left(\mathrm{CH}_{3}, \mathrm{C}-25\right), 15.4\left(\mathrm{CH}_{3}\right.$, $\mathrm{C}-22), 15.2\left(\mathrm{CH}_{3}, \mathrm{C}-15\right)$; HRESIMS $m / z$ 415.2851 $(\mathrm{M}+\mathrm{H})^{+}$(calculated for $\mathrm{C}_{26} \mathrm{H}_{39} \mathrm{O}_{4}, 415.2848$ ).

\subsubsection{Pyripyropene S (6)}

Yellow viscous liquid, $[\alpha]_{\mathrm{D}}{ }^{20}+116.3\left(c 0.04, \mathrm{CHCl}_{3}\right)$; IR (KBr) $v_{\max } 2923,2851,1742,1671,1624$, 1586, 1508, 1465, 1374, 1242, $1043 \mathrm{~cm}^{-1}$; ${ }^{1} \mathrm{H}$ and ${ }^{13} \mathrm{C}$ NMR (Table 3); HRESIMS $\mathrm{m} / z$ 566.2415 $(\mathrm{M}+\mathrm{H})^{+}$(calculated for $\left.\mathrm{C}_{31} \mathrm{H}_{36} \mathrm{NO}_{9}, 566.2390\right)$.

\subsection{X-ray Crystal Structure of Chevalone E (3)}

Crystals suitable for X-ray diffraction were obtained by slow evaporation of a solution in petroleum ether/chloroform. They were orthorhombic, space group P2 ${ }_{12}{ }_{12}$, cell volume 2310.9(1) $\AA^{3}$ and unit cell dimensions $a=8.2325(2) \AA, b=11.3341(3) \AA$ and $c=24.7665(6) \AA$. Diffraction data were collected at $293 \mathrm{~K}$ with a Gemini PX Ultra equipped with $\mathrm{CuK}_{\alpha}$ radiation $(\lambda=1.54184 \AA)$. The structures were solved by direct methods using SHELXS-97 and refined with SHELXL-97. Carbon, oxygen and nitrogen atoms were refined anisotropically. Hydrogen atoms were refined freely with isotropic displacement parameters. The refinement converged to $R$ (all data) $=6.38 \%$ and $w R_{2}$ (all data) $=10.21 \%$. Towards the end of refinement the absolute structure parameter $x$ (Flack $x$ parameter) was refined at the same time as all other parameters, using the TWIN instruction with the default matrix $\mathrm{R}=(-100,0-1$ $0,00-1)$ and BASF with one parameter $(x)$, to reach the final value of $x=0.0$ (3). The inverted structure, obtained with the instruction MOVE $111-1$, yielded $x=1.5$ (3). Tables containing the final fractional coordinates, temperature parameters, bond distances, and bond angles were deposited with the Cambridge Crystallographic Data Centre: CCDC reference number 1002416.

\subsection{Antimicrobial Activity Assays}

\subsubsection{Bacterial Strains}

For the antimicrobial assays, the compounds were tested against: bacterial reference strains (Staphylococcus aureus ATCC 25923, Bacillus subtilis ATCC 6633, Escherichia coli ATCC 25922 and 
Pseudomonas aeruginosa ATCC 27853), Candida albicans ATCC 10231 and multidrug-resistant bacteria isolated from the environment, $S$. aureus B1 (isolated from public bus), Enterococcus faecalis W1 (isolated from river water) and E. coli G1 (isolated from seagull feces). Bacteria were grown in Mueller-Hinton agar (MH-BioKar diagnostics, Allonne, France) from stock cultures, while C. albicans was grown in Sabouraud dextrose agar (SAB-BioKar diagnostics, Allonne, France). MH and SAB plates were incubated at $37{ }^{\circ} \mathrm{C}$ prior to obtain fresh cultures for each in vitro bioassay.

\subsubsection{Determination of Minimum Inhibitory and Bactericidal/Fungal Concentrations}

The minimum inhibitory concentrations (MIC) of the compounds were determined using a broth microdilution technique, following the recommendations of the Clinical and Laboratory Standards Institute [17]. Stock solutions of $10 \mathrm{mg} / \mathrm{mL}$, prepared in dimethylsulfoxide (DMSO-Applichem GmbH, Darmstadt, Germany), were serially diluted in Mueller-Hinton broth (MHB-BioKar diagnostics, Allonne, France) to achieve in-test concentrations ranging from 2 to $256 \mu \mathrm{g} / \mathrm{mL}$. Each bacterial inoculum was prepared in MHB, while C. albicans inoculum was prepared in RPMI-1640 with L-glutamine, with MOPS and without $\mathrm{NaHCO}_{3}$ (Lonza, Walkersville, MD, USA). All inocula were standardized in order obtain a concentration of $5 \times 10^{5} \mathrm{CFU} / \mathrm{mL}$ in each inoculated well of the microtiter plate. The concentration of DMSO in the highest in-test concentration did not affect the microbial growth. The MIC was defined as the lowest concentration of compound that has inhibited the visible growth.

\subsubsection{Synergistic Studies}

\subsubsection{Screening of Combined Effect between the Compounds and Antibiotics}

A screening susceptibility test to assess the combined effect between the compounds and antibiotics was conducted using the disc diffusion method on $\mathrm{MH}$, according to the procedure already described by Gomes et al. [9].

\subsubsection{Synergy Test: Checkerboard Method}

Based on the results of the previous assay, potential synergy between $\mathbf{3}$ and oxacillin or ampicillin (Sigma-Aldrich, St. Louis, MO, USA) was checked using a broth microdilution checkerboard method and tested in MRSA isolate (S. aureus B1), as has been already described [9]. Two independent experiments in duplicate were performed. The fractional inhibitory concentration (FIC) was calculated as follows: FIC of drug A (FIC A) = MIC of drug A in combination/MIC of drug A alone, and FIC of $\operatorname{drug} \mathrm{B}(\mathrm{FIC} \mathrm{B})=\mathrm{MIC}$ of drug B in combination/MIC of drug B alone. The FIC index ( $\Sigma$ FIC), calculated as the sum of each FIC, was interpreted as follows: $\Sigma$ FIC $\leq 0.5$, synergy; $0.5<\Sigma F I C \leq 4$, no interaction; $4<\Sigma$ FIC, antagonism [18].

\section{Conclusions}

Although several analogs of chevalone have been reported from several members of the genus Aspergillus, this is the first report of isolation of isocoumarin derivatives from a member of this genus. 
The synergism of chevalone $\mathrm{E}$ with the antibiotic oxacillin against MRSA can be considered relevant for anti-infective marine natural products research.

\section{Acknowledgments}

This work was partially supported by the Project MARBIOTECH (reference NORTE-07-0124FEDER-000047) within the SR\&TD Integrated Program MARVALOR-Building research and innovation capacity for improved management and valorization of marine resources, supported by the Programa Operacional Regional do Norte (ON.2-O Novo Norte) and by the European Regional Development Fund, and also by FCT-Fundação para a Ciência e a Tecnologia under the project CEQUIMED-PEst-OE/SAU/UI4040/2014, FEDER funds through the COMPETE program under the project FCOMP-01-0124-FEDER-011057. We thank Mick Lee of the Department of Chemistry, Leicester University (UK), for providing the HRESIMS. C.P. thanks the Faculty of Pharmaceutical Sciences, Burapha University, Thailand for her scholarship to the University of Porto. We thank Júlia Bessa and Sara Cravo for technical support.

\section{Author Contributions}

Prompanya, C. performed isolation, purification and structure elucidation of some compounds; Kijjoa, A. and Pinto, M.M.M. conceived, designed the research, elucidated the structure of the compounds and wrote the paper; Dethoup, T. isolated, identified, cultured the fungi, and prepared the crude extract; Gales, L. performed X-ray crystallography of compound 3; Silva, A.M.S. provided the NMR spectra; Bessa, L.J. and Costa, P.M. performed antibacterial activity.

\section{Conflicts of Interest}

The authors declare no conflict of interest.

\section{References}

1. Asami, Y.; Kakeya, H.; Onose, R.; Yoshida, A.; Matsuzaki, H.; Osada, H. Azaspirene: A novel angiogenesis inhibitor containing a 1-oxa-7-azaspiro[4.4]non-2-ene-4,6-dione skeleton produced by the fungus Neosartorya sp. Org. Lett. 2002, 4, 2845-2848.

2. Asami, Y.; Kakeya, H.; Onose, R.; Chang, Y.H.; Toi, M.; Osada, H. RK-805, an endothelial-cell-growth inhibitor produced by Neosartorya sp., and a docking model with methionine aminopeptidase- 2 . Tetrahedron 2004, 60, 7085-7091.

3. Jayasuriya, H.; Zink, D.; Basilio, A.; Vicente, F.; Collado, J.; Bills, G.; Goldman, M.L.; Motyl, M.; Huber, J.; Dezeny, G.; et al. Discovery and antibacterial activity of glabramycin A-C from Neosartorya glabra by an antisense strategy. J. Antibiotics 2009, 62, 265-269.

4. Yang, S.S.; Wang, G.J.; Cheng, K.F.; Chen, C.H.; Ju, Y.M.; Tsau, Y.J.; Lee, T.H. Bioactive $\gamma$-lactones from the fermented broth of Neosartorya sp. Planta Med. 2010, 76, 1701-1705.

5. Kijjoa, A.; Santos, S.; Dethoup, T.; Manoch, L.; Almeida, A.P.; Vasconcelos, M.H.; Silva, A.; Gales, L.; Herz, W. Sartoryglabrins, analogs of ardeemins, from Neosartorya glabra. Nat. Prod. Commun. 2011, 6, 807-812. 
6. Eamvijarn, A.; Kijjoa, A.; Bruyère, C.; Mathieu, V.; Manoch, V.; LeFranc, F.; Silva, A.; Kiss, R.; Herz, W. Secondary metabolites from a culture of the fungus Neosartorya pseudofischeri and their in vitro cytostatic activity in human cancer cells. Planta Med. 2012, 78, 1767-1776.

7. Buttachon, S.; Chandrapatya, A.; Manoch, L.; Silva, A.; Gales, L.; Bruyère, C.; Kiss, R.; Kijjoa, A. Sartorymensin, a new indole alkaloid, and new analogues of tryptoquivaline and fiscalins produced by Neosartorya siamensis (KUFC 6349). Tetrahedron 2012, 68, 3253-3262.

8. Eamvijarn, A.; Gomes, N. M.; Dethoup, T.; Buaruang, J.; Manoch, L.; Silva, A.; Pedro, M.; Marini, I.; Roussis, V.; Kijjoa, A. Bioactive meroditerpenes and indole alkaloids from the soil fungus Neosartorya fischeri (KUFC 6344), and the marine-derived fungi Neosartorya laciniosa (KUFC 7896) and Neosartorya tsunodae (KUFC 9213). Tetrahedron 2013, 69, 8583-8591.

9. Gomes, N.M.; Bessa, L.J.; Buttachon, S.; Costa, P.M.; Buaruang, J.; Dethoup, T.; Silva, A.M.S.; Kijjoa, A. Antibacterial and Antibiofilm activities of tryptoquivalines and meroditerpenes isolated from the marine-derived fungi Neosartorya paulistensis, N. laciniosa, N. tsunodae, and the Soil Fungi N. fischeri and N. siamensis. Mar. Drugs 2014, 12, 822-839.

10. Kanokmedhakul, K.; Kanokmedhakul, S.; Suwannatrai, R.; Soytong, K.; Prabpai, S.; Kongsaeree, P. Bioactive meroterpenoids and alkaloids from the fungus Eurotium chevalieri. Tetrahedron 2011, 67, 5461-5468.

11. Ryoo, I.J.; Xu, G.H.; Km, Y.H.; Choo, S.J.; Ahn, J.S.; Bae, K.; Yoo, I.D. Reticulone, a novel free radical scavenger produced by Aspergillus sp. J. Microbiol. Biotechnol. 2009, 12, 1573-1575.

12. Gallo, M.B.C.; Cavalcanti, B.C.; Barros, F.W.A.; Moraes, M.O.; Costa-Latufo, L.V.; Pessoa, C.; Bastos, J.K.; Pupo, M.T. Chemical constituents of Papulaspora immersa, an endophyte from Smallanthus sonchifolius (Asteraceae), and their cytotoxic activity. Chem. Biodivers. 2010, 7 , 2941-2950.

13. Erkel, G.; Rether, J.; Anke, T. S14-95, a novel inhibitor of the JAK/STAT pathway from a Penicillium species. J. Antibiotics 2003, 56, 337-343.

14. Tomoda, H.; Tabata, N.; Yang, D.J.; Takaya.naki, H.; Nishida, M.; Omura, S. Pyripyropenes, novel ACAT inhibitors produced by Aspergillus fumigatus. III. Structure elucidation of pyripyropenes E to L. J. Antibiotics 1995, 48, 495-503.

15. Obata, R.; Sunazuka, T.; Tomoda, H.; Harigaya, Y.; Omura, S. Chemical Modification and structure-activity relationships of pyripyropenes, potent, bioavailable inhibitor of acyl-CoA: cholesterol $O$-acyltransferase (ACAT). Bioorg. Med. Chem. Lett. 1995, 5, 2683-2688.

16. Glass, N.L.; Donaldson, G.C. Development of primer sets designed for use with the PCR to amplify conserved genes from filamentous ascomycetes. Appl. Environ. Microbiol. 1995, 61, 1323-1330.

17. Franklin, R.; Cockerill, M.D., III. Performance Standards for Antimicrombial Susceptibility Testing. Twenty-First Informational Supplement M100-S21; Clinical and Laboratory Standards Institute (CLSI): Wayne, PA, USA, 2011.

18. Odds, F.C. Synergy, antagonism, and what the chequerboard puts between them. J. Antimicrob. Chemother 2003, 52, 1.

(C) 2014 by the authors; licensee MDPI, Basel, Switzerland. This article is an open access article distributed under the terms and conditions of the Creative Commons Attribution license (http://creativecommons.org/licenses/by/4.0/). 